\title{
Acute Inflammatory Painful Polyradiculoneuritis
}

\author{
An Uncommon Presentation Related to COVID-19
}

\author{
Francisco Antunes Dias, MD, MSc, Ana Luiza Nunes Cunha, MD, MSc, Patrícia Maria Pedrosa Pantoja, MD, \\ Carolina Lavigne Moreira, MD, MSc, Pedro José Tomaselli, MD, PhD, Maria Clara Zanon Zotin, MD, MSc, \\ Francisco Antônio Colleto, MD, MSc, Soraia Ramos Cabette Fabio, MD, PhD, Octavio M. Pontes-Neto, MD, PhD, \\ and Wilson Marques Júnior, MD, PhD
}

Neurology: Clinical Practice April 2021 vol. 11 no. 2 e205-e207 doi:10.1212/CPJ.0000000000000910

\author{
Correspondence \\ Dr. Dias \\ franciscodias.neuro@usp.br
}

Coronavirus disease 2019 (COVID-19), caused by severe acute respiratory syndrome coronavirus 2 (SARS-CoV-2), has emerged in Wuhan, China, in December 2019, and the World Health Organization has declared it a pandemic in March 2020. Since then, severe neurologic complications associated with COVID-19 have been described, including encephalitis and stroke. Recently, it has been recognized that acute neuropathies may also occur. ${ }^{2,3}$ Herein, we report a patient with COVID-19 presenting an acute refractotoy painful polyradiculoneuritis.

\section{Case}

A 38-year-old man presented with a 5-day history of fever, dry cough, and fatigue, followed by respiratory distress. His chest $\mathrm{CT}$ revealed bilateral ground-glass opacities, and he was admitted to the intensive care unit (ICU) requiring mechanical ventilation. His medical history included Class I obesity, regular alcohol, and cigarette consumption. He was treated with oseltamivir, hydroxychloroquine, azithromycin, and antibiotics for nosocomial pneumonia. Nasopharyngeal RTPCR for SARS-CoV-2 was positive on days 1 and 12. He received a tetravalent vaccine for influenza on day 6. Sedation was discontinued 15 days after ICU admission, when he started complaining of proximally excruciating pain in both legs. Although strength and deep tendon reflexes were preserved, he was diagnosed with critical illness polyneuropathy by the ICU team, and morphine, duloxetine, and pregabaline were started. He was discharged 20 days after admission with persisting pain and negative RT-PCR.

Five days after hospital discharge, he was evaluated by a neurologist, reporting a visual analogue scale (VAS) for pain of 10 in 10 (10/10). Treatment was adjusted (duloxetine, pregabaline, amitriptyline, morphine, and vitamins supplementation), and in few days, his VAS turned 0/10. However, 1 week later, his painful manifestations returned, including tingling paresthesia and burning pain distally in lower limbs. At this time, his neurologic examination showed weakness in muscles of L5 myotomal distribution bilaterally, and pinprick-evoked pain reduced distally on both feet, accompanied by intense tactile allodynia. Deep tendon reflexes, vibration, and proprioception were normal. He had flexor plantar responses bilaterally. Cranial nerves were normal. There were no dysautonomic or sphincter abnormalities. Nerve conductions studies, including $\mathrm{F}$ waves, were within normal limits, and concentric needle examination showed signs of acute denervation in lumbosacral muscles innervated by right L4-L5-S1 and left L5-S1 roots (figure and table). Spinal cord MRI revealed enhancement of L5 bilaterally. CSF revealed albuminocytologic dissociation (cells: 0; protein: $76 \mathrm{mg} / \mathrm{dL}$ ). An acute painful inflammatory polyradiculoneuritis was suspected, and high-dose intravenous human immunoglobulin (IVIG

\section{MORE ONLINE}

COVID-19 Resources

For the latest articles, invited commentaries, and blogs from physicians around the world NPub.org/COVID19

Department of Neurosciences and Behavioral Sciences (FAD, ALNC, PMPP, CLM, PJT, FAC, OMP-N, WMJ), Hospital das Clínicas—Ribeirão Preto Medical School, University of São Paulo; Department of Radiology (MCZZ), Hospital das Clínicas-Ribeirão Preto Medical School, University of São Paulo; Department of Neurology (MCZZ), Massachusetts General Hospital, Harvard Medical School, Boston, MA; and Hospital da Unimed Ribeirão Preto (SRCF), São Paulo, Brazil.

Funding information and disclosures are provided at the end of the article. Full disclosure form information provided by the authors is available with the full text of this article at Neurology.org/cp. 


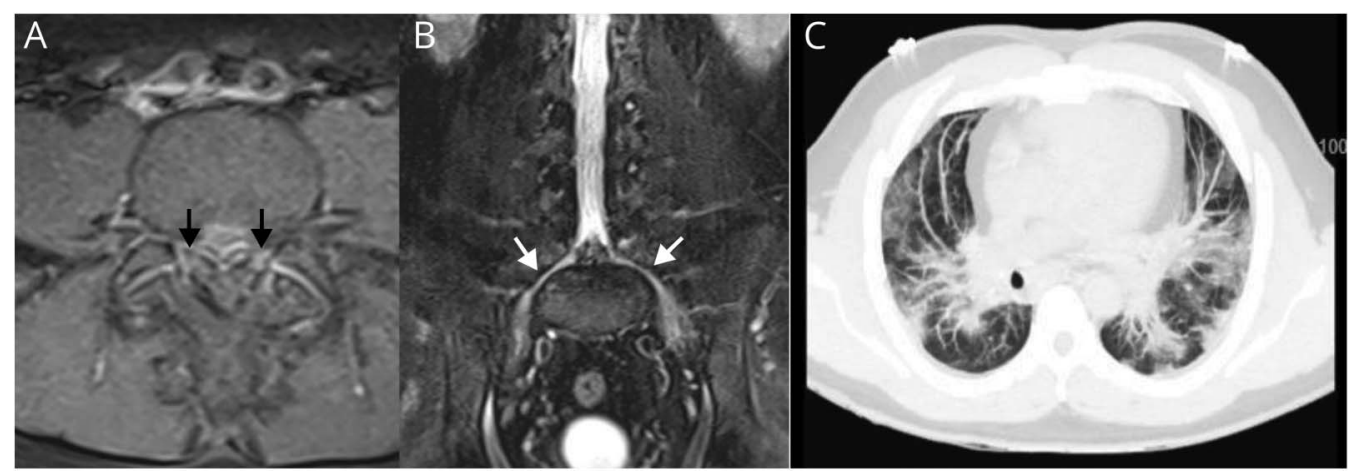

(A) T1-weighted postcontrast axial with fat suppression reveals enhancement of bilateral L5 roots (black arrows). (B) T2-weighted coronal with fat suppression shows hyperintensity of bilateral L5 nerves (white arrows). (C) Chest CT with bilateral ground-glass opacities.

$0.4 \mathrm{~g} / \mathrm{kg}$ for 5 days) was prescribed. He has been stable (VAS $3-4 / 10$ ) on the following 2 weeks. At the last visit to the neurologist, 3 weeks after IVIG infusion, the patient reported significant clinical improvement, persisting only with mild radicular pain on both legs.

\section{Discussion}

We described a case of acute inflammatory painful polyradiculoneuritis and suggest that it could be an atypical neurologic manifestation related to COVID-19 infection.

Recently, acute neuropathies have been described in relation to COVID-19. Toscano et al. ${ }^{4}$ reported 5 patients with COVID-19 diagnosed as having Guillain-Barré syndrome (GBS). All had severe SARS-CoV-2 infection, and neurologic symptoms emerged within the first 10 days (parainfectious profile). Four of 5 presented lower-limb flaccid weakness and arreflexia that progressed to flaccid tetraparesis/tetraplegia. Two had high CSF protein levels, and 3 had been classified as an axonal variant. Another report described a patient with severe polyradiculoneuritis leading to a locked-in syndrome. ${ }^{5}$ By contrast, our patient had a clinical profile restricted to lower limbs and predominantly painful, considered an acute inflammatory lumbosacral polyradiculoneuritis.

In addition, 3 Chinese patients presenting an acute painful autoimmune small-fiber neuropathy were described. ${ }^{6}$ They had antecedent infectious disease, presented clinically with severe pain distally in a glove-and-stocking distribution plus dysautonomia and also albuminocytologic dissociation. These key aspects (previous infectious disease, acute painful neuropathy, and albuminocytologic dissociation) are present in our patient's history and support the autoimmune nature of the peripheral nerve involvement. The symptoms evolved to the lumbosacral roots, as corroborated by MRI and EMG findings, leading us to classify it as a polyradiculoneuritis rather than a diffuse small-fiber neuropathy.

Table Nerve Conduction Studies

\begin{tabular}{|c|c|c|c|c|c|c|c|c|c|}
\hline \multirow[b]{2}{*}{ Nerve } & \multicolumn{7}{|c|}{ CMAP } & \multicolumn{2}{|c|}{ SNAP } \\
\hline & $\mathbf{L}$ & A1 & $A 2$ & A3 & CV1-2 & CV2-3 & Fw & A & $\mathrm{CV}$ \\
\hline R median & 3.0 & 13.9 & 13.5 & 13.1 & 55,1 & 68.8 & 26.3 & 28.5 & 54.3 \\
\hline L median & 3.1 & 9.2 & 7.9 & 7.5 & 62.0 & 54.8 & 26.1 & 23.4 & 56.3 \\
\hline R ulnar & 2.2 & 7.5 & 6.7 & 6.4 & 64.6 & 65.7 & 26.0 & 12.3 & 61.0 \\
\hline L ulnar & 2.6 & 7.8 & 6.9 & 6.3 & 62.3 & 55.9 & 25.8 & 14.8 & 55.3 \\
\hline R peroneiro & 4.6 & 4.24 & 4.03 & 3.97 & 41.4 & 44.4 & 48.3 & 7.7 & 40.1 \\
\hline L peroneiro & 4.4 & 4.67 & 4.21 & 4.19 & 45.8 & 43.9 & 44.3 & 6.7 & 45.0 \\
\hline $\mathrm{R}$ tibialis posterior & 4.2 & 12.6 & 11.2 & - & 50.6 & - & 45.4 & 4.7 & 55.6 \\
\hline L tibialis posterior & 3.9 & 16.2 & 10.4 & - & 43.6 & - & 44.5 & 5.9 & 59.5 \\
\hline
\end{tabular}

Abbreviations: $\mathrm{A}=$ amplitude $(\mathrm{mV}$ for $\mathrm{CMAP} / \mu \mathrm{V}$ for SAP); $\mathrm{CMAP}=$ compound muscle action potential; $\mathrm{CV}=$ conduction velocity $(\mathrm{m} / \mathrm{s}) ; \mathrm{FW}=\mathrm{minimum} \mathrm{F}$ wave latency (ms); $\mathrm{L}=$ distal latency $(\mathrm{ms}) ; \mathrm{SAP}=$ sensory action potential.

Median and ulnar nerves: 1 = wrist; 2 = elbow; 3 = axila; Peroneal nerve: 1 = ankle; 2 = below fibula neck, 3 = above fibula neck; Tibial posterior nerve: 1 = ankle 2 = poplitae fossa. 
Neuropathic pain has already been described in patients with COVID-19. ${ }^{2}$ Because no additional information was provided, it is possible that they also had a polyradiculoneuritis, similar to our case. Previous exposure to seasonal influenza vaccination should be considered a confounding causal factor, but recent epidemiologic studies question the association of this vaccine and GBS. ${ }^{7}$ Unfortunately, we were unable to perform RT-PCR on the CSF to exclude a direct lesion by the virus.

In conclusion, our case report suggests that patients with COVID-19 may develop an acute inflammatory painful polyradiculoneuritis that seems to respond to IVIG.

\section{Study Funding}

No targeted funding reported.

\section{Disclosure}

The authors report no disclosures relevant to the manuscript. Full disclosure form information provided by the authors is available with the full text of this article at Neurology.org/cp.

\section{Publication History}

Received by Neurology: Clinical Practice June 7, 2020. Accepted in final form July 7, 2020.

\begin{tabular}{|c|c|c|}
\hline Name & Location & Contribution \\
\hline $\begin{array}{l}\text { Francisco } \\
\text { Antunes } \\
\text { Dias, MD, } \\
\text { MSc }\end{array}$ & $\begin{array}{l}\text { Department of Neurosciences } \\
\text { and Behavioral Sciences, } \\
\text { Hospital das } \\
\text { Clínicas-Ribeirão Preto } \\
\text { Medical School, University of } \\
\text { São Paulo; Ribeirão Preto, SP, } \\
\text { Brazil }\end{array}$ & $\begin{array}{l}\text { Designed and } \\
\text { conceptualized study, } \\
\text { analyzed the data, and } \\
\text { drafted the manuscript } \\
\text { for intellectual content }\end{array}$ \\
\hline $\begin{array}{l}\text { Ana Luiza } \\
\text { Nunes } \\
\text { Cunha, MD, } \\
\text { MSc }\end{array}$ & $\begin{array}{l}\text { Department of Neurosciences } \\
\text { and Behavioral Sciences, } \\
\text { Hospital das } \\
\text { Clínicas-Ribeirão Preto } \\
\text { Medical School, University of } \\
\text { São Paulo; Ribeirão Preto, SP, } \\
\text { Brazil }\end{array}$ & $\begin{array}{l}\text { Interpreted the data and } \\
\text { revised the manuscript } \\
\text { for intellectual content }\end{array}$ \\
\hline $\begin{array}{l}\text { Patrícia } \\
\text { Maria } \\
\text { Pedrosa } \\
\text { Pantoja, MD }\end{array}$ & $\begin{array}{l}\text { Department of Neurosciences } \\
\text { and Behavioral Sciences, } \\
\text { Hospital das } \\
\text { Clínicas-Ribeirão Preto } \\
\text { Medical School, University of } \\
\text { São Paulo; Ribeirão Preto, SP, } \\
\text { Brazil }\end{array}$ & $\begin{array}{l}\text { Interpreted the data and } \\
\text { revised the manuscript } \\
\text { for intellectual content }\end{array}$ \\
\hline $\begin{array}{l}\text { Carolina } \\
\text { Lavigne } \\
\text { Moreira, MD, } \\
\text { MSc }\end{array}$ & $\begin{array}{l}\text { Department of Neurosciences } \\
\text { and Behavioral Sciences, } \\
\text { Hospital das } \\
\text { Clínicas-Ribeirão Preto } \\
\text { Medical School, University of } \\
\text { São Paulo; Ribeirão Preto, SP, } \\
\text { Brazil }\end{array}$ & $\begin{array}{l}\text { Interpreted the data and } \\
\text { revised the manuscript } \\
\text { for intellectual content }\end{array}$ \\
\hline $\begin{array}{l}\text { Pedro José } \\
\text { Tomaselli, } \\
\text { MD, PhD }\end{array}$ & $\begin{array}{l}\text { Department of Neurosciences } \\
\text { and Behavioral Sciences, } \\
\text { Hospital das } \\
\text { Clínicas-Ribeirão Preto } \\
\text { Medical School, University of } \\
\text { São Paulo; Ribeirão Preto, SP, } \\
\text { Brazil }\end{array}$ & $\begin{array}{l}\text { Interpreted the data and } \\
\text { revised the manuscript } \\
\text { for intellectual content }\end{array}$ \\
\hline
\end{tabular}

Appendix (continued)

\begin{tabular}{|c|c|c|}
\hline Name & Location & Contribution \\
\hline $\begin{array}{l}\text { Maria Clara } \\
\text { Zanon Zotin, } \\
\text { MD, MSc }\end{array}$ & $\begin{array}{l}\text { Department of Radiology, } \\
\text { Hospital das } \\
\text { Clínicas-Ribeirão Preto } \\
\text { Medical School, University } \\
\text { of São Paulo; Ribeirão Preto, } \\
\text { SP, Brazil; Department of } \\
\text { Neurology, Massachusetts } \\
\text { General Hospital, Harvard } \\
\text { Medical School, Boston, MA }\end{array}$ & $\begin{array}{l}\text { Interpreted the data and } \\
\text { revised the manuscript } \\
\text { for intellectual content }\end{array}$ \\
\hline $\begin{array}{l}\text { Francisco } \\
\text { Antônio } \\
\text { Colleto, MD, } \\
\text { MSc }\end{array}$ & $\begin{array}{l}\text { Department of } \\
\text { Neurosciences and } \\
\text { Behavioral Sciences, } \\
\text { Hospital das } \\
\text { Clínicas-Ribeirão Preto } \\
\text { Medical School, University } \\
\text { of São Paulo; Ribeirão Preto, } \\
\text { SP, } \\
\text { Brazil }\end{array}$ & $\begin{array}{l}\text { Major role in the } \\
\text { acquisition of data }\end{array}$ \\
\hline $\begin{array}{l}\text { Soraia } \\
\text { Ramos } \\
\text { Cabette } \\
\text { Fabio, MD, } \\
\text { PhD }\end{array}$ & $\begin{array}{l}\text { Hospital da Unimed } \\
\text { Ribeirão Preto, Ribeirão } \\
\text { Preto, SP, Brazil }\end{array}$ & $\begin{array}{l}\text { Major role in the } \\
\text { acquisition of data }\end{array}$ \\
\hline $\begin{array}{l}\text { Octavio M. } \\
\text { Pontes-Neto, } \\
\text { MD, PhD }\end{array}$ & $\begin{array}{l}\text { Department of } \\
\text { Neurosciences and } \\
\text { Behavioral Sciences, } \\
\text { Hospital das } \\
\text { Clínicas-Ribeirão Preto } \\
\text { Medical School, University } \\
\text { of São Paulo; Ribeirão Preto, } \\
\text { SP, } \\
\text { Brazil }\end{array}$ & $\begin{array}{l}\text { Interpreted the data and } \\
\text { revised the manuscript } \\
\text { for intellectual content }\end{array}$ \\
\hline $\begin{array}{l}\text { Wilson } \\
\text { Marques } \\
\text { Júnior, MD, } \\
\text { PhD }\end{array}$ & $\begin{array}{l}\text { Department of } \\
\text { Neurosciences and } \\
\text { Behavioral Sciences, } \\
\text { Hospital das } \\
\text { Clínicas-Ribeirão Preto } \\
\text { Medical School, University } \\
\text { of São Paulo; Ribeirão Preto, } \\
\text { SP, } \\
\text { Brazil }\end{array}$ & $\begin{array}{l}\text { Interpreted the data and } \\
\text { revised the manuscript } \\
\text { for intellectual content }\end{array}$ \\
\hline
\end{tabular}

\section{References}

1. Wang $\mathrm{D}, \mathrm{Hu} \mathrm{B}, \mathrm{Hu} \mathrm{C}$, et al. Clinical characteristics of 138 hospitalized patients with 2019 novel coronavirus-infected pneumonia in Wuhan, China. JAMA 2020;323: 1061-1069.

2. Mao L, Jin H, Wang M, et al. Neurologic manifestations of hospitalized patients with coronavirus disease 2019 in Wuhan, China. JAMA Neurol 2020;77: $1-9$.

3. Moriguchi T, Harii N, Goto J, et al. A first case of meningitis/encephalitis associated with SARS-coronavirus-2. Int J Infect Dis 2020;94:55-58.

4. Toscano G, Palmerini F, Ravaglia S, et al. Guillain-Barré syndrome associated with SARS-CoV-2. N Engl J Med 2020;382:2574-2576.

5. Pfefferkorn T, Dabitz R, von Wernitz-Keibel T, et al. Acute polyradiculoneuritis with locked-in syndrome in a patient with covid-19. J Neurol 2020;267: 1883-1884.

6. Yuki N, Chan AC, Wong AHY, et al. Acute painful autoimmune neuropathy: a variant of Guillain-Barré syndrome. Muscle Nerve 2018;57:320-324.

7. Grave C, Boucheron P, Rudant J, et al. Seasonal influenza vaccine and GuillainBarré syndrome: a self-controlled case series study. Neurology 2020;94: e2168-e2179. 


\section{Neurology ${ }^{\circ}$ Clinical Practice}

\section{Acute Inflammatory Painful Polyradiculoneuritis: An Uncommon Presentation Related to COVID-19}

Francisco Antunes Dias, Ana Luiza Nunes Cunha, Patrícia Maria Pedrosa Pantoja, et al. Neurol Clin Pract 2021;11;e205-e207 Published Online before print July 28, 2020 DOI 10.1212/CPJ.0000000000000910

This information is current as of July 28, 2020

Updated Information \&
Services

References

Subspecialty Collections

Permissions \& Licensing

Reprints including high resolution figures, can be found at: http://cp.neurology.org/content/11/2/e205.full.html

This article cites 7 articles, 1 of which you can access for free at: http://cp.neurology.org/content/11/2/e205.full.html\#\#ref-list-1

This article, along with others on similar topics, appears in the following collection(s):

COVID-19

http://cp.neurology.org//cgi/collection/covid_19

EMG

http://cp.neurology.org//cgi/collection/emg

Guillain-Barre syndrome

http://cp.neurology.org//cgi/collection/guillainbarre_syndrome Neuropathic pain

http://cp.neurology.org//cgi/collection/neuropathic_pain Peripheral neuropathy http://cp.neurology.org//cgi/collection/peripheral_neuropathy

Information about reproducing this article in parts (figures,tables) or in its entirety can be found online at:

http://cp.neurology.org/misc/about.xhtml\#permissions

Information about ordering reprints can be found online: http://cp.neurology.org/misc/addir.xhtml\#reprintsus

Neurol Clin Pract is an official journal of the American Academy of Neurology. Published continuously since 2011, it is now a bimonthly with 6 issues per year. Copyright $\odot 2020$ American Academy of Neurology. All rights reserved. Print ISSN: 2163-0402. Online ISSN: 2163-0933.

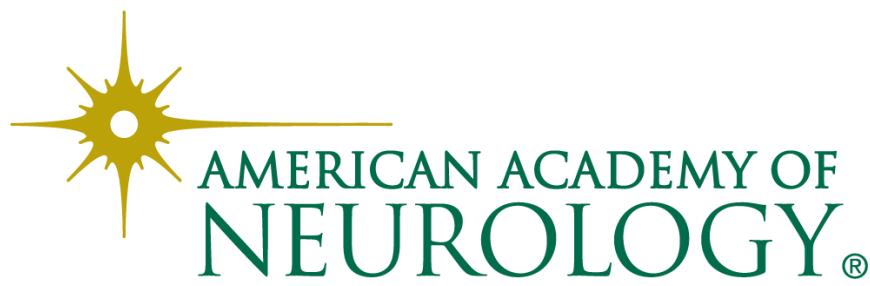

